\title{
PHOSPHORUS IN VARIOUS DEPTHS OF SOME VIRGIN PEAT LANDS
}

\author{
ARMi KaILA \\ Department of Agricultural Chemistry, University of Helsinki
}

Received January 23, 1956.

The nutrition conditions of virgin peat lands offer an interesting object to soil scientists and plant ecologists. In spite of the fairly low content of most of the nutrients in peat, large amounts are stored up in the growing peat deposits. In more advanced peat formations the mineral subsoil has no longer any importance as a source of nutrients for the surface vegetation. This is supported by the more or less low quantities of nutrients carried in the water which flows from the neighbourhood or in the air as dust, and of course, by the nutrients rendered available from the dying parts of vegetation and from the peat which slowly decomposes.

Very little is known of these processes, and particularly the phosphorus economy of peat lands is obscure. According to the common view the phosphorus content of Finnish virgin peat soils is fairly low, and apparently, only a very small part of this total phosphorus occurs in forms available to plants. It is obvious that a rather hard competition for the available phosphorus takes place between the plants on one hand and the micro-organisms and chemical and physical factors on the other hand.

In order to elucidate the problems concerning the phosphorus economy and particularly the phosphorus cycle in peat soils a series of investigation was started. At first the forms and solubility of phosphorus in various depths of some peat lands were studied. These results are reported in the present paper.

\section{Material and methods}

The material of this investigation consisted of 122 peat samples collected from various depths of 30 uncultivated peat lands, most of them in Northern Fin- 
land. These peat lands represented the following surface vegetation types and degrees of land quality (Bo, from 1 to 10 ).

1. Sphagnum fuscum pine bog, Bo 1 .

$2 . \quad \longrightarrow-\quad$ Bo 1, partly drained.

3-4. Carex globularis pine bog, Bo 2.

5. Raised bog, drained for fuel peat.

6. Treeless Sphagnum fuscum bog, Bo 1, drained.

7. Oligotrophic water-logged Sphagnum bog occupying hollows, Bo $1-2$.

8. Sphagnum papillosum bog, treeless, Bo $1-2$.

9-11. Sphagnum papillosum - Scirpus caespitosus treeless bog, Bo 2.

12-13. Sphagnum papillosum - Carex lasiocarpa treeless bog, Bo 3.

14-18. Sphagnum papillosum - Carex limosa treeless bog, Bo 3.

19. Mesotrophic Sphagnum papillosum treeless bog, Bo 6.

20-21. Water-logged Carex limosa bog, treeless, Bo 4.

22. Oligotrophic water-logged treeless bog without mosses, Bo 4.

23. Flooded bog, without trees, Bo 5.

24. Mesotrophic water-logged treeless Carex bog, Bo 6 .

25-26. Sphagnum Warnstorfii fen, Bo 8.

27-29. Scorpidium scorpioides fen, Bo 7.

30. Eutrophic water-logged treeless bog without mosses, Bo 8 .

Since the purpose of this investigation was to study the phosphorus cycle from the point of view of surface vegetation, the samples were mostly taken from the surface layer down to about $100 \mathrm{~cm}$. In some cases also a sample of the surface vegetation was collected. The three series of samples from the number 30 were taken from the depth of $40 \mathrm{~cm}$ down to the mineral subsoil which lies in various depths in different parts of this peat land.

The peat type and the degree of humification by von Post were determined from the fresh samples in the field. All the other analyses were performed using samples which were air-dried and ground.

The soil $\mathrm{pH}$ was determined in water suspension (1:4) by a Beckman pHmeter. The volume weight was estimated with a simple apparatus developed in this laboratory by Mr. Jaakko Kivekäs M. A. and explained elsewhere (3).

The phosphorus analyses were performed using the molybdenum-blue method in the modification developed by the author (2). The total phosphorus was determined from a Kjeldahl-digest; organic phosphorus was estimated by the acidalkali extraction method and by an ignition procedure and reported as an average of the results of these two methods (4). Total inorganic phosphorus corresponds to the amount extracted by the acid-alkali treatment. The inorganic phosphorus soluble in $0.5 \mathrm{~N}$ acetic acid was extracted in the ratio of 1 to 20 , whereas the inorganic phosphorus soluble in $0.2 \mathrm{~N}$ sulphuric acid was extracted in the ratio of 1 to 100 . In both cases the time of extraction was one hour. 
Some of the samples were also analyzed for inorganic and organic phosphorus soluble in various $\mathrm{pH}$-area. These extractions were performed with $0.05 \mathrm{~N}$ hydrochloric acid and $0.05 \mathrm{~N}$ sodium hydroxide mixed in various ratios:
1. 3 parts of $\mathrm{HCl}+1$ part of $\mathrm{NaOH}$, corresponding to $\mathrm{pH} 2.0-2.5$
2. $2 \longrightarrow$ - $\begin{array}{llll}2 & -1- & \mathrm{pH} 3.5-4.5\end{array}$

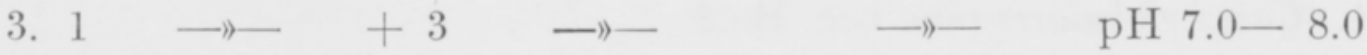
4. $0.05 \mathrm{~N} \mathrm{NaOH}, \quad \longrightarrow-\quad \mathrm{pH} 9.0-10.0$.

The organic phosphorus represents the difference between the total and inorganic phosphorus of these extracts. The total phosphorus was estimated on aliquotes digested with perchloric acid (4).

\section{Total and organic phosphorus}

In Table 1 the total and organic phosphorus contents of the peat soils are reported. Also some other characteristics of the samples are listed.

No very marked differences seem to exist between the kind of peat in various layers of the same profile: the older deposits contain slightly more Carex-residues than the younger ones in which the Sphagnum material is generally more common. The degree of humification may increase considerably with the increasing depth, although it in some cases appears to be almost unchanged by the age of the layer.

The $\mathrm{pH}$-values appear to change only little or not at all in the same profile, in spite of changes in the kind of peat and in its degree of humification. Sometimes a slight tendency to increase with the depth can be observed. The weight of volume is mostly low. Also the figures for the ash content show that the samples do not contain mineral matter.

The total phosphorus content of all the samples varies from $190 \mathrm{ppm}$ to 1810 ppm expressed as P. Values for P higher than $1000 \mathrm{ppm}$ are, however, rare. No significant difference exists between the total $\mathrm{P}$ content of the peat lands of lower quality and that of the better ones. Both the poorest profile, 5b, and the richest one, 3 , can be found among the former group. As to the influence of depth on the content of total phosphorus no clear regularity can be observed. There seems to be some tendency to an increase in the P-content with increasing depth in the peat lands of lower quality, in peat lands of higher quality the opposite often holds true.

A very large part of phosphorus in all these peat lands occurs in organic form, and almost without exception this relative amount of organic phosphorus is the higher the deeper the peat layer in question. In the fresh plant material the amount of phosphorus found to be in organic form by the analytical methods employed represents from 50 to 60 per cent of the total phosphorus. In the surface layer this percentage is higher, on the average about 70 per cent; in the deposits deeper than $50 \mathrm{~cm}$ there are seldom less than 80 per cent of the total phosphorus in organic form. The highest relative amount of organic phosphorus obtained was 95 per cent. 
Table 1. Total and organic phosphorus content of various layers of the peat lands.

\begin{tabular}{|c|c|c|c|c|c|c|c|c|c|c|}
\hline \multirow[b]{2}{*}{ No } & \multirow{2}{*}{$\begin{array}{l}\text { Depth } \\
\text { dm }\end{array}$} & \multirow{2}{*}{$\begin{array}{c}\text { Kind } \\
\text { of } \\
\text { peat }\end{array}$} & \multirow[b]{2}{*}{$\mathrm{H}$} & \multirow[b]{2}{*}{$\mathrm{pH}$} & \multirow[b]{2}{*}{$\mathrm{w} / \mathrm{v}$} & \multirow{2}{*}{$\begin{array}{c}\text { Ash } \\
\%\end{array}$} & \multirow{2}{*}{$\begin{array}{l}\text { Total } \\
\text { P ppm }\end{array}$} & \multirow{2}{*}{$\begin{array}{c}\text { Org. P } \\
\text { ppm }\end{array}$} & \multicolumn{2}{|c|}{ Org. $\mathrm{P} \%$ of } \\
\hline & & & & & & & & & tot. P & $\begin{array}{c}\text { org. } \\
\text { matter }\end{array}$ \\
\hline 1 & 2 & 3 & 4 & 5 & 6 & 7 & 8 & 9 & 10 & 11 \\
\hline \multirow[t]{3}{*}{1.} & $0-3$ & $\mathrm{~S}$ & 1 & 4.2 & 0.08 & 5.9 & 480 & 320 & 67 & 0.03 \\
\hline & $4-6$ & $\mathrm{~S}$ & 1 & 4.4 & 0.08 & 3.9 & 390 & 300 & 77 & 0.03 \\
\hline & $6-8$ & $\mathrm{CS}$ & 5 & 4.5 & 0.25 & 5.8 & 770 & 660 & 86 & 0.07 \\
\hline \multirow[t]{3}{*}{2.} & $2-4$ & $\mathrm{~S}$ & 2 & 5.0 & 0.14 & 2.8 & 580 & 400 & 69 & 0.04 \\
\hline & $4-6$ & $\mathrm{LCS}$ & 5 & 5.0 & 0.32 & 2.0 & 610 & 470 & 77 & 0.05 \\
\hline & $6-8$ & $\mathrm{SC}$ & 4 & 5.1 & 0.35 & 2.2 & 450 & 360 & 80 & 0.04 \\
\hline \multirow[t]{3}{*}{3.} & $1-2$ & $\mathrm{~S}$ & 1 & 4.5 & 0.11 & 4.2 & 970 & 660 & 68 & 0.07 \\
\hline & $2-3$ & $\mathrm{~S}$ & 2 & 4.6 & 0.17 & 4.5 & 1180 & 890 & 76 & 0.09 \\
\hline & $3-4$ & $\mathrm{CS}$ & 5 & 4.6 & 0.39 & 5.5 & 1810 & 1570 & 87 & 0.17 \\
\hline \multirow[t]{3}{*}{4.} & $0-3$ & $\mathrm{LCS}$ & 1 & 4.2 & 0.09 & 3.4 & 770 & 510 & 66 & 0.05 \\
\hline & $3-5$ & $\mathrm{LCS}$ & 4 & 4.4 & 0.25 & 9.7 & 1310 & 1110 & 85 & 0.12 \\
\hline & $7-10$ & LCS & 5 & 4.3 & .0 .36 & 6.2 & 1510 & 1340 & 89 & 0.14 \\
\hline \multirow[t]{3}{*}{$5 a}$. & $2-3$ & LS & 3 & 3.7 & 0.29 & 4.4 & 570 & 430 & 76 & 0.04 \\
\hline & $3-4$ & LS & 5 & 3.8 & 0.49 & 4.3 & 620 & 520 & 84 & 0.05 \\
\hline & $7-10$ & LS & 7 & 4.4 & 0.38 & 6.3 & 710 & 560 & 79 & 0.06 \\
\hline \multirow[t]{3}{*}{$5 \mathrm{~b}$} & $3-5$ & $\mathrm{~S}$ & 1 & 4.7 & 0.10 & 1.0 & 190 & 140 & 74 & 0.01 \\
\hline & $5-7$ & ErS & 3 & 4.9 & 0.23 & 2.1 & 360 & 270 & 75 & 0.03 \\
\hline & $12-14$ & ErS & 3 & 4.7 & 0.21 & 2.9 & 370 & 290 & 79 & 0.03 \\
\hline \multirow[t]{3}{*}{6.} & $0-2$ & $\mathrm{~S}$ & 1 & 4.5 & 0.11 & 4.9 & 840 & 590 & 70 & 0.06 \\
\hline & $2-4$ & $\mathrm{CS}$ & 2 & 4.6 & 0.23 & 5.0 & 760 & 550 & 72 & 0.06 \\
\hline & $4-6$ & $\mathrm{CS}$ & 4 & 4.6 & 0.25 & 4.3 & 840 & 700 & 83 & 0.07 \\
\hline \multirow[t]{4}{*}{7.} & $0-2$ & $\mathrm{~S}$ & 1 & 3.7 & 0.05 & 1.4 & 400 & 250 & 63 & 0.03 \\
\hline & $2-5$ & $\mathrm{~S}$ & 2 & 3.6 & 0.09 & 1.5 & 470 & 320 & 68 & 0.03 \\
\hline & $6-9$ & $\mathrm{~S}$ & 4 & 3.8 & 0.21 & 2.9 & 680 & 500 & 73 & 0.05 \\
\hline & $9-11$ & $\mathrm{~S}$ & 6 & 4.2 & 0.32 & 2.4 & 630 & 540 & 86 & 0.06 \\
\hline \multirow[t]{4}{*}{8.} & \multicolumn{3}{|c|}{ Plant matter } & 4.3 & 0.07 & 7.2 & 430 & 250 & 58 & 0.03 \\
\hline & $0-2$ & $\mathrm{~S}$ & 1 & 3.9 & 0.29 & 5.7 & 850 & 620 & 73 & 0.07 \\
\hline & $3-5$ & S & 3 & 4.0 & 0.34 & 4.0 & 760 & 590 & 78 & 0.06 \\
\hline & $8-10$ & $\mathrm{SC}$ & 5 & 4.1 & 0.30 & 3.1 & 630 & 500 & 79 & 0.05 \\
\hline 9. & & nt ma & & 4.4 & 0.06 & 6.9 & 390 & 230 & 59 & 0.02 \\
\hline & $0-3$ & $\mathrm{~S}$ & 1 & 4.5 & 0.12 & 5.2 & 380 & 290 & 76 & 0.03 \\
\hline & $5-7$ & $\mathrm{CS}$ & 4 & 4.3 & 0.30 & 3.5 & 440 & 330 & 75 & 0.03 \\
\hline & $8-10$ & $\mathrm{CS}$ & 5 & 4.1 & 0.35 & 4.0 & 550 & 460 & 84 & 0.05 \\
\hline 10. & & nt ma & & 4.3 & 0.10 & 5.8 & 390 & 230 & 59 & 0.02 \\
\hline & $1-3$ & $\mathrm{CS}$ & 3 & 3.8 & 0.33 & 7.8 & 700 & 490 & 70 & 0.05 \\
\hline & $3-5$ & $\mathrm{SC}$ & 7 & 4.2 & 0.42 & 11.0 & 520 & 400 & 77 & 0.04 \\
\hline 11. & $0-2$ & $\mathrm{CS}$ & 1 & 5.1 & 0.11 & 7.7 & 460 & 260 & 57 & 0.03 \\
\hline & $3-5$ & $\mathrm{CS}$ & 3 & 5.2 & 0.14 & 6.5 & 510 & 380 & 75 & 0.04 \\
\hline & $7-10$ & $\mathrm{CS}$ & 5 & 5.3 & 0.31 & 4.9 & 650 & 550 & 85 & 0.06 \\
\hline 12. & & nt ma & & 4.5 & 0.07 & 7.9 & 410 & 260 & 63 & 0.03 \\
\hline & $0-2$ & $\mathrm{~S}$ & 1 & 4.4 & 0.28 & 10.8 & 530 & 360 & 68 & 0.04 \\
\hline & $3-5$ & $\mathrm{C}$ & 3 & 4.5 & 0.29 & 10.0 & 550 & 400 & 73 & 0.04 \\
\hline 13. & & int ma & & 4.5 & 0.09 & 8.5 & 580 & 360 & 62 & 0.04 \\
\hline & $1-3$ & $\mathrm{SC}$ & 4 & 4.3 & 0.34 & 6.2 & 1230 & 860 & 70 & 0.09 \\
\hline & $3-5$ & LC & 7 & 4.6 & 0.31 & 5.3 & 890 & 760 & 86 & 0.08 \\
\hline
\end{tabular}




\begin{tabular}{|c|c|c|c|c|c|c|c|c|c|c|}
\hline 1 & 2 & 3 & 4 & 5 & 6 & 7 & 8 & 9 & 10 & 11 \\
\hline \multirow[t]{3}{*}{14.} & $0-2$ & $\mathrm{~S}$ & 1 & 4.2 & 0.09 & 5.0 & 730 & 550 & 75 & 0.06 \\
\hline & $2-3$ & $\mathrm{SC}$ & 3 & 4.9 & 0.34 & 6.1 & 1180 & 900 & 77 & 0.10 \\
\hline & $4-6$ & $\mathrm{C}$ & 5 & 4.9 & 0.34 & 6.1 & 1070 & 940 & 88 & 0.10 \\
\hline \multirow[t]{4}{*}{15.} & \multicolumn{3}{|c|}{ Plant matter } & 4.9 & 0.07 & 22.6 & 1010 & 520 & 52 & 0.07 \\
\hline & $0-2$ & $\mathrm{SC}$ & 3 & 4.9 & 0.26 & 16.7 & 560 & 440 & 79 & 0.05 \\
\hline & $3-5$ & $\mathrm{SC}$ & 2 & 4.8 & 0.25 & 4.0 & 500 & 420 & 84 & 0.04 \\
\hline & $8-10$ & $\mathrm{SC}$ & 2 & 4.8 & 0.20 & 6.5 & 480 & 440 & 92 & 0.05 \\
\hline \multirow[t]{4}{*}{16.} & \multicolumn{3}{|c|}{ Plant matter } & 4.4 & 0.09 & 12.9 & 430 & 240 & 56 & 0.03 \\
\hline & $2-4$ & $\mathrm{SC}$ & 4 & 4.3 & 0.34 & 6.5 & 680 & 550 & 81 & 0.06 \\
\hline & $6-8$ & $\mathrm{SC}$ & 3 & 4.5 & 0.30 & 3.7 & 440 & 420 & 95 & 0.04 \\
\hline & $8-10$ & $\mathrm{C}$ & 5 & 4.1 & 0.31 & 5.5 & 550 & 500 & 91 & 0.05 \\
\hline \multirow[t]{4}{*}{17.} & \multicolumn{3}{|c|}{ Plant matter } & 4.5 & 0.07 & 7.3 & 580 & 330 & 57 & 0.04 \\
\hline & $1-3$ & $\mathrm{SC}$ & 2 & 5.0 & 0.25 & 12.3 & 540 & 400 & 74 & 0.05 \\
\hline & $4-6$ & $\mathrm{SC}$ & 4 & 4.2 & 0.30 & 5.8 & 750 & 650 & 87 & 0.07 \\
\hline & $8-10$ & $\mathrm{C}$ & 7 & 5.8 & 0.37 & 7.2 & 660 & 590 & 89 & 0.06 \\
\hline \multirow[t]{4}{*}{18.} & \multicolumn{3}{|c|}{ Plant matter } & 4.8 & 0.09 & 5.9 & 680 & 400 & 59 & 0.04 \\
\hline & $1--3$ & $\mathrm{SC}$ & 2 & 4.7 & 0.38 & 8.0 & 1260 & 860 & 68 & 0.09 \\
\hline & $5-6$ & LC & 3 & 5.0 & 0.34 & 5.5 & 850 & 720 & 85 & 0.08 \\
\hline & $8-9$ & $\mathrm{C}$ & 6 & 5.1 & 0.37 & 8.7 & 910 & 800 & 88 & 0.09 \\
\hline \multirow[t]{4}{*}{19.} & \multicolumn{3}{|c|}{ Plant matter } & 4.8 & 0.09 & 8.3 & 740 & 430 & 58 & 0.05 \\
\hline & $0-2$ & $\mathrm{C}$ & 3 & 4.7 & 0.30 & 5.5 & 810 & 650 & 80 & 0.07 \\
\hline & $3-5$ & $\mathrm{C}$ & 3 & 4.8 & 0.25 & 5.1 & 470 & 370 & 79 & 0.04 \\
\hline & $8-10$ & $\mathrm{C}$ & 4 & 4.9 & 0.23 & 4.2 & 500 & 400 & 80 & 0.04 \\
\hline \multirow[t]{3}{*}{20.} & $0-1$ & $\mathrm{SC}$ & 3 & 4.4 & 0.27 & 9.8 & 1270 & 1000 & 79 & 0.11 \\
\hline & $1-3$ & C & 4 & 4.9 & 0.28 & 5.1 & 1060 & 880 & 83 & 0.09 \\
\hline & $5-7$ & $\mathrm{C}$ & 4 & 5.1 & 0.26 & 4.9 & 890 & 730 & 82 & 0.08 \\
\hline \multirow[t]{3}{*}{21.} & $0-2$ & $\mathrm{SC}$ & 4 & 5.5 & 0.27 & 15.4 & 570 & 440 & 77 & 0.05 \\
\hline & $3-5$ & C & 7 & 5.4 & 0.46 & 8.1 & 750 & 540 & 72 & 0.06 \\
\hline & $6-8$ & $\mathrm{C}$ & 6 & 5.4 & 0.30 & 4.8 & 870 & 620 & 71 & 0.07 \\
\hline \multirow[t]{3}{*}{22} & $0-2$ & $\mathrm{SC}$ & 3 & 4.4 & 0.21 & 4.7 & 830 & 560 & 67 & 0.06 \\
\hline & $3-5$ & $\mathrm{SC}$ & 5 & 4.5 & 0.29 & 2.6 & 570 & 450 & 79 & 0.05 \\
\hline & $7-10$ & $\mathrm{SC}$ & 6 & 5.2 & 0.30 & 4.0 & 840 & 690 & 82 & 0.07 \\
\hline \multirow[t]{3}{*}{23.} & $0-2$ & $\mathrm{SC}$ & 3 & 3.6 & 0.23 & 24.4 & 1070 & 780 & 73 & 0.10 \\
\hline & $3-9$ & $\mathrm{SC}$ & 5 & 3.5 & 0.32 & 3.5 & 1100 & 890 & 81 & 0.09 \\
\hline & $10-13$ & $\mathrm{SC}$ & 7 & 4.2 & 0.40 & 13.2 & 1290 & 990 & 77 & 0.11 \\
\hline \multirow[t]{3}{*}{24.} & $1-3$ & C & 3 & 4.6 & 0.21 & 4.5 & 1140 & 930 & 82 & 0.10 \\
\hline & $5-7$ & C & 3 & 4.2 & 0.20 & 3.1 & 1210 & 920 & 76 & 0.10 \\
\hline & $11-14$ & $\mathrm{LC}$ & 4 & 4.4 & 0.23 & 5.3 & 1240 & 1080 & 87 & 0.11 \\
\hline \multirow[t]{3}{*}{25.} & $0-2$ & EuSC & 3 & 4.4 & 0.18 & 18.4 & 1500 & 1110 & 74 & 0.14 \\
\hline & $3-7$ & EuSC & 5 & 4.7 & 0.32 & 4.9 & 750 & 600 & 80 & 0.06 \\
\hline & $8-10$ & EuSC & 7 & 4.3 & 0.38 & 5.1 & 500 & 400 & 80 & 0.04 \\
\hline \multirow[t]{3}{*}{26.} & $0-2$ & EuSC & 2 & 5.8 & 0.18 & 9.1 & 1470 & 1230 & 84 & 0.14 \\
\hline & $3-5$ & EuSC & 4 & 5.9 & 0.36 & 8.2 & 820 & 690 & 84 & 0.08 \\
\hline & $7-10$ & EuSC & 6 & 5.8 & 0.41 & 8.9 & 770 & 650 & 84 & 0.07 \\
\hline \multirow[t]{3}{*}{27.} & $0-1$ & $\mathrm{BC}$ & 1 & 4.9 & 0.16 & 9.9 & 580 & 400 & 69 & 0.04 \\
\hline & $2-3$ & $\mathrm{BC}$ & 2 & 5.2 & 0.24 & 15.6 & 530 & 430 & 81 & 0.05 \\
\hline & $5-7$ & $\mathrm{BC}$ & 7 & 5.0 & 0.37 & 10.6 & 610 & 490 & 81 & 0.05 \\
\hline 28 & $0-2$ & $\mathrm{BC}$ & 3 & 3.9 & 0.26 & 4.3 & 750 & 500 & 67 & 0.05 \\
\hline & $3-5$ & $\mathrm{BC}$ & 5 & 4.4 & 0.34 & 3.3 & 610 & 500 & 82 & 0.05 \\
\hline
\end{tabular}




\begin{tabular}{|c|c|c|c|c|c|c|c|c|c|c|}
\hline 1 & 2 & 3 & 4 & 5 & 6 & 7 & 8 & 9 & 10 & 11 \\
\hline & $7-10$ & $\mathrm{BC}$ & 6 & 4.9 & 0.45 & 4.6 & 680 & 530 & 78 & 0.06 \\
\hline \multirow[t]{3}{*}{29} & $0-2$ & $\mathrm{BC}$ & 1 & 5.5 & 0.14 & 9.0 & 340 & 200 & 59 & 0.02 \\
\hline & $3-5$ & $\mathrm{BC}$ & 3 & 5.2 & 0.28 & 7.5 & 660 & 530 & 80 & 0.06 \\
\hline & $7-9$ & $\mathrm{BC}$ & 6 & 5.3 & 0.34 & 4.4 & 520 & 420 & 81 & 0.04 \\
\hline \multirow[t]{7}{*}{$30 \mathrm{a}}$. & $4-7$ & $\mathrm{BC}$ & 4 & 4.9 & 0.30 & 4.4 & 370 & 300 & 81 & 0.03 \\
\hline & $10-13$ & $\mathrm{BC}$ & 3 & 4.9 & 0.25 & 3.7 & 270 & 210 & 78 & 0.02 \\
\hline & $14-17$ & $\mathrm{BC}$ & 3 & 4.9 & 0.24 & 4.8 & 290 & 220 & 76 & 0.02 \\
\hline & $17-20$ & $\mathrm{BC}$ & 3 & 4.8 & 0.25 & 4.7 & 330 & 250 & 75 & 0.03 \\
\hline & $20-23$ & $\mathrm{BC}$ & 3 & 4.8 & 0.27 & 5.9 & 320 & 240 & 75 & 0.03 \\
\hline & $24-27$ & $\mathrm{BC}$ & 5 & 5.0 & 0.36 & 5.1 & 410 & 320 & 78 & 0.03 \\
\hline & $27-30$ & $\mathrm{C}$ & 6 & 5.0 & 0.35 & 8.2 & 450 & 350 & 78 & 0.04 \\
\hline \multirow[t]{6}{*}{$30 \mathrm{~b}$} & $4-7$ & $\mathrm{BC}$ & 3 & 5.6 & 0.28 & 6.7 & 530 & 430 & 81 & 0.05 \\
\hline & $7-10$ & $\mathrm{BC}$ & 4 & 5.4 & 0.29 & 7.5 & 530 & 470 & 88 & 0.05 \\
\hline & $10-13$ & BCS & 5 & 5.4 & 0.37 & 6.5 & 450 & 390 & 87 & 0.04 \\
\hline & $14-17$ & BCS & 6 & 5.3 & 0.39 & 7.0 & 540 & 460 & 85 & 0.05 \\
\hline & $17-20$ & EuSC & 6 & 5.2 & 0.41 & 7.5 & 670 & 590 & 88 & 0.06 \\
\hline & $20-23$ & EuSC & 7 & 5.4 & 0.47 & 19.2 & 1040 & 920 & 88 & 0.11 \\
\hline \multirow[t]{5}{*}{$30 \mathrm{c}}$. & $4-10$ & $\mathrm{BC}$ & 6 & 5.7 & 0.43 & 15.3 & 1130 & 980 & 87 & 0.12 \\
\hline & $10-13$ & $\mathrm{BC}$ & 6 & 5.8 & 0.44 & 9.8 & 1120 & 970 & 87 & 0.11 \\
\hline & $14-17$ & $\mathrm{BC}$ & 6 & 5.7 & 0.42 & 11.8 & 900 & 780 & 87 & 0.09 \\
\hline & $17-20$ & LC & 7 & 5.6 & 0.39 & 12.9 & 530 & 460 & 87 & 0.05 \\
\hline & $20-23$ & $\mathrm{C}$ & 6 & 5.5 & 0.43 & 11.3 & 660 & 580 & 88 & 0.07 \\
\hline
\end{tabular}

It is difficult to find out whether this increase in the relative amount of organic phosphorus with increasing depth is connected only with the age of the peat or does the degree of humification play the significant role. The total correlation coefficient between the relative amount of organic phosphorus and the depth of the sampling layer is $r=0.685$, and that for the relative amount of organic phosphorus and the degree of humification is $r=0.688$. But also the degree of humification and the depth of the sampling layer are closely correlated, the coefficient being $\mathrm{r}=0.732$. All these coefficients are significant at the 0.1 per cent level. Thus the statistical treatment of this material does not help to solve the problem: the partial correlation coefficients between the relative amount of organic phosphorus and the depth or the degree of humification are, after the elimination of the effect of the degree of humification or that of the depth, resp. $r=0.368$ and $\mathrm{r}=0.373$, both significant at the 0.1 per cent level. In these calculations the samples of numbers $30 \mathrm{a}, 30 \mathrm{~b}$ and $30 \mathrm{c}$ were excluded, since they represent only the bottom layers of the peat land.

The amount of organic phosphorus expressed as a percentage of the organic matter is calculated in order to obtain an idea of the possibilities of mineralization. In organic matter in which the carbon compounds are available for microorganisms, mineralization of organic phosphorus can be detected as soon as the amount of organic phosphorus exceeds the limit of about 0.2 per cent of dry matter (1). This has been found to be an average value under normal conditions. Under 
conditions of low oxidation-reduction potentials, as those which prevail in virgin peat lands, this limit can be markedly lower. Also the fact that the carbon compounds in peat and in residues of peat land plants are not easily available tends to decrease the limit value. The amount of organic phosphorus in all the samples varies from 0.01 to 0.17 per cent of organic dry matter, but most of the figures are low: only in 11 samples the amount is higher than 0.1 per cent. Generally this quantity increases with the increase in depth, or with the increase in the degree of humification. In the surface layers it is, however, so low that the mineralization of organic phosphorus compounds probably cannot exceed the rate of synthetic processes. Only in a few of the peat lands of better quality, e.g. in the numbers 25 and 26, the amount of organic phosphorus in the surface samples is markedly higher than 0.1 per cent of organic dry matter. In these cases a net mineralization of phosphorus seems from the microbiological point of view to be possible. However, also other factors than the energy economy of the system must be taken into consideration, e.g. the chemical retention of organic phosphorus compounds in insoluble forms which are unavailable to the microorganisms.

In Table 1 the amounts of phosphorus were reported on the weight basis. This, however, does not give a clear picture of the conditions in nature, owing to the differences in the volume weights of peat from various depths and with various degrees of humification. Data expressed on the volume basis probably would better correspond to the natural conditions. Unfortunately, in connection with this work only the volume weights determined on the air-dry and ground samples were available. Thus the results calculated on the basis of these values cannot represent the real amounts in nature. Therefore, they are not completely reported in this connection.

Owing to the low volume weight of the surface peat the increase in the amounts of phosphorus with the depth must be more distinct when expressed on the volume basis than when expressed on the weight basis. Yet, there are some parts of the profiles in which also the values of phosphorus per volume were higher in the surface layers than in the lower layers. Such cases are e.g. numbers 20 and 25 .

Particularly interesting are the numbers 8-10,12, 13, 15-19 which contain the layer of undecomposed plant material. In all these cases the phosphorus content of this material is markedly lower than that of the more or less decomposed peat below it. This was also true when the phosphorus content was expressed on the weight basis, except in number 15. These results do not seem to be in accordance with some earlier reports. Kivinen (5) claims that the peat land plants are richer in phosphorus than the peat which they form. This may be true, but it is not quite easy to prove. If the material used by Kivinen is examined in detail, it can be found that the phosphorus content of the plants are often lower than that of the peat collected from the same place. This holds true for all the 17 samples of Sphagnum fuscum for which analyses of the corresponding peat samples are available; further for two of the three samples of Sphagnum papillosum, for 19 of the 23 samples of Sphagnum Warnstorfii, and even for 10 of the 17 samples of Eriophorum latifolium, one of the four samples of Molinia coerulea, and 21 of the 
40 samples of Menyanthes trifoliata. The Carex plants can also contain total phosphorus less than the peat on which they grow. These results become even more marked when the fact is taken into consideration that the plant samples were mostly collected in July and in August, or during a period of vigorous growth, when the percentage of nutrients in the plants may be higher than at the stage of maturity.

The plant samples of the present investigation were taken from Sphagnum papillosum bogs, and this moss formed the largest part of the material. It is, therefore, quite natural that the phosphorus content of these plant mixtures is determined predominantly by the low P content of Spagnum papillosum. The results yielded by the data reported by Kivinen (5) show that also in peat lands of better quality the phosphorus content of various plants can be lower than that of the peat on which they grow.

\section{Solubility of inorganic and organic phosphorus}

In Table 2 some data concerning the amount and solubility of inorganic phosphorus in various depths of some of these peat lands are listed.

The most striking feature of the results in Table 2 is the decrease in the amount of more or less easily soluble inorganic phosphorus with the increase in the depth. In all the series of the samples both the acetic acid soluble inorganic phosphorus and the phosphorus soluble in diluted sulphuric acid are highest in the surface samples and generally show a marked drop in the deeper layers. It is of interest to notice that similar trends can be found also in the solubility of inorganic phosphorus into $4 \mathrm{~N}$ sulphuric acid during a treatment for 18 hours connected with a thorough washing with water. An opposite tendency is shown by the data obtained by extractions with cold and hot alkali, $0.5 \mathrm{~N}$ sodium hydroxide, which succeeded the treatment with $4 \mathrm{~N}$ sulphuric acid. Thus the total amount of inorganic phosphorus does not markedly decrease with the increase in depth.

Consequently, the conclusion may be drawn that the solubility of inorganic phosphorus in peat is highest in the surface and it decreases on going deeper. This view is corroborated by the results reported in Table 3 in which the solubility in various $\mathrm{pH}$-ranges of inorganic and organic phosphorus of some of these profiles is presented. In this connection the solubility means the amount of phosphorus extracted from a $5 \mathrm{~g}$-sample during one hour by $100 \mathrm{ml}$ of four mixtures of $0.05 \mathrm{~N}$ hydrochloric acid and sodium hydroxide. The $\mathrm{pH}$ was measured both from the extract filtrated through paper and from the wet soil on the filter. The corresponding values did not significantly differ from each other. The figures in Table 3 are averages of these values. Owing to the very low volume weight of some of the surface samples the ratio of 1 to 40 had to be chosen for the extraction. This, of course, impairs the comparability of the results to some extent, but, on the other hand, it must be remembered that in this way the volumes of peat extracted became more equal. 
Table 2. Inorganic phosphorus in various layers of the peat lands.

\begin{tabular}{|c|c|c|c|c|c|c|c|c|}
\hline \multirow{3}{*}{ No } & \multirow{3}{*}{$\begin{array}{l}\text { Depth } \\
\mathrm{dm}\end{array}$} & \multirow{3}{*}{$\begin{array}{l}\text { Kind } \\
\text { of } \\
\text { peat }\end{array}$} & \multirow{3}{*}{$\mathrm{H}$} & \multicolumn{5}{|c|}{ Inorganic $\mathrm{P}$ ppm } \\
\hline & & & & \multicolumn{5}{|c|}{ extracted by } \\
\hline & & & & total & $0.5 \mathrm{~N} \mathrm{HAc}$ & $0.2 \mathrm{~N} \mathrm{H}_{2} \mathrm{SO}_{4}$ & $4 \mathrm{~N} \mathrm{H}_{2} \mathrm{SO}_{1}$ & $+0.5 \mathrm{~N} \mathrm{NaOH}$ \\
\hline 1 & 2 & 3 & 4 & 5 & 6 & 7 & 8 & 9 \\
\hline \multirow[t]{3}{*}{1.} & $0-3$ & $\mathrm{~S}$ & 1 & 160 & 46 & 70 & 80 & 80 \\
\hline & $4-6$ & $\mathrm{~S}$ & 1 & 90 & 24 & 50 & 40 & 50 \\
\hline & $6-8$ & $\mathrm{CS}$ & 5 & 110 & 10 & 20 & 20 & 90 \\
\hline \multirow[t]{3}{*}{2.} & $2-4$ & $\mathrm{~S}$ & 2 & 180 & 57 & 50 & 140 & 40 \\
\hline & $4-6$ & LCS & 5 & 140 & 25 & 40 & 60 & 80 \\
\hline & $6-8$ & $\mathrm{SC}$ & 4 & 90 & 8 & 10 & 30 & 60 \\
\hline \multirow[t]{3}{*}{3.} & $1-2$ & $\mathrm{~S}$ & 1 & 310 & 21 & 140 & 260 & 50 \\
\hline & $2-3$ & $\mathrm{~S}$ & 2 & 290 & 14 & 160 & 220 & 70 \\
\hline & $3-4$ & $\mathrm{CS}$ & 5 & 240 & 5 & 70 & 100 & 140 \\
\hline \multirow[t]{3}{*}{4.} & $0-3$ & $\mathrm{LCS}$ & 1 & 260 & 73 & 240 & 220 & 40 \\
\hline & $3-5$ & LCS & 4 & 300 & 20 & 70 & 200 & 100 \\
\hline & $7-10$ & LCS & 5 & 170 & 5 & 10 & 30 & 140 \\
\hline \multirow[t]{3}{*}{$5 a}$. & $2-3$ & LS & 3 & 140 & 14 & 30 & 50 & 90 \\
\hline & $3-4$ & LS & 5 & 100 & 15 & 30 & 30 & 70 \\
\hline & $7-10$ & $\mathrm{LS}$ & 7 & 150 & 1 & 10 & 40 & 110 \\
\hline \multirow[t]{3}{*}{$5 \mathrm{~b}$} & $3-5$ & $\mathrm{~S}$ & 1 & 50 & 7 & 0 & 10 & 40 \\
\hline & $5-7$ & ErS & 3 & 90 & 5 & 0 & 10 & 80 \\
\hline & $12-14$ & ErS & 3 & 80 & 4 & 10 & 10 & 70 \\
\hline \multirow[t]{3}{*}{6.} & $0-2$ & S & 1 & 250 & 55 & 90 & 150 & 100 \\
\hline & $2-4$ & $\mathrm{CS}$ & 2 & 210 & 50 & 60 & 80 & 130 \\
\hline & $4-6$ & $\mathrm{CS}$ & 4 & 140 & 14 & 20 & 30 & 110 \\
\hline \multirow[t]{4}{*}{7.} & $0-2$ & $\mathrm{~S}$ & 1 & 150 & 60 & 50 & 140 & 10 \\
\hline & $2-5$ & $\mathrm{~S}$ & 2 & 150 & 60 & 20 & 90 & 60 \\
\hline & $6-9$ & $\mathrm{~S}$ & 4 & 180 & 16 & 15 & 90 & 90 \\
\hline & $9-11$ & $\mathrm{~S}$ & 6 & 90 & 4 & 1 & 50 & 40 \\
\hline \multirow[t]{4}{*}{8.} & \multicolumn{3}{|c|}{ Plant matter } & 180 & - & 100 & 120 & 60 \\
\hline & $0-2$ & $\mathrm{~S}$ & 1 & 230 & 29 & 50 & 130 & 100 \\
\hline & $3-5$ & $\mathrm{~S}$ & 3 & 170 & 9 & 30 & $20^{*}$ & 150 \\
\hline & $8-10$ & $\mathrm{SC}$ & 5 & 130 & - & 20 & 10 & 120 \\
\hline \multirow[t]{4}{*}{9.} & \multicolumn{3}{|c|}{ Plant matter } & 160 & - & 80 & 90 & 70 \\
\hline & $0-3$ & S & 1 & 90 & 8 & 40 & 40 & 50 \\
\hline & $5-7$ & CS & 4 & 110 & 4 & 20 & 20 & 90 \\
\hline & $8-10$ & $\mathrm{CS}$ & 5 & 90 & 3 & 20 & 20 & 70 \\
\hline \multirow[t]{3}{*}{10.} & \multicolumn{3}{|c|}{ Plant matter } & 160 & - & 110 & 90 & 70 \\
\hline & $1-3$ & CS & 3 & 210 & 1 & 30 & 110 & 100 \\
\hline & $3-5$ & $\mathrm{SC}$ & 7 & 120 & 1 & 20 & 20 & 100 \\
\hline \multirow[t]{3}{*}{12.} & \multicolumn{3}{|c|}{ Plant matter } & 150 & - & 90 & 90 & 60 \\
\hline & $0-2$ & $\mathrm{~S}$ & 1 & 170 & 5 & 50 & 60 & 110 \\
\hline & $3-5$ & $\mathrm{C}$ & 3 & 150 & 7 & 20 & 30 & 120 \\
\hline 13. & & t matter & & 220 & - & 110 & 150 & 70 \\
\hline & $1-3$ & $\mathrm{SC}$ & 4 & 370 & 2 & 60 & 210 & 160 \\
\hline & $3-5$ & LC & 7 & 120 & 3 & 10 & 10 & 110 \\
\hline
\end{tabular}




\begin{tabular}{|c|c|c|c|c|c|c|c|c|}
\hline 1 & 2 & 3 & 4 & 5 & 6 & 7 & 8 & 9 \\
\hline \multirow[t]{3}{*}{14.} & $0-2$ & $\mathrm{~S}$ & 1 & 180 & 5 & 60 & 90 & 90 \\
\hline & $2-3$ & $\mathrm{SC}$ & 3 & 280 & 4 & 50 & 70 & 210 \\
\hline & $4-6$ & $\mathrm{C}$ & 5 & 130 & 1 & 10 & 20 & 110 \\
\hline \multirow[t]{4}{*}{15.} & \multicolumn{3}{|c|}{ Plant matter } & 490 & - & 280 & 450 & 40 \\
\hline & $0-2$ & $\mathrm{SC}$ & 3 & 120 & 7 & 20 & 70 & 50 \\
\hline & $3-5$ & $\mathrm{SC}$ & 2 & 80 & 3 & 10 & 10 & 70 \\
\hline & $8-10$ & $\mathrm{SC}$ & 2 & 40 & - & 10 & 30 & 10 \\
\hline \multirow[t]{4}{*}{16.} & \multicolumn{3}{|c|}{ Plant matter } & 190 & - & 90 & 140 & 50 \\
\hline & $2-4$ & $\mathrm{SC}$ & 4 & 130 & 6 & 10 & 30 & 100 \\
\hline & $6-8$ & $\mathrm{SC}$ & 3 & 20 & 4 & 10 & 10 & 10 \\
\hline & $8-10$ & $\mathrm{C}$ & 5 & 50 & - & 10 & 20 & 30 \\
\hline \multirow[t]{4}{*}{17.} & \multicolumn{3}{|c|}{ Plant matter } & 250 & - & 180 & 210 & 40 \\
\hline & $1-3$ & $\mathrm{SC}$ & 2 & 140 & 19 & 20 & 80 & 60 \\
\hline & $4-6$ & $\mathrm{SC}$ & 4 & 100 & 13 & 10 & 50 & 50 \\
\hline & $8-10$ & $\mathrm{C}$ & 7 & 70 & 5 & 10 & 20 & 50 \\
\hline \multirow[t]{4}{*}{18.} & \multicolumn{3}{|c|}{ Plant matter } & 280 & - & 200 & 240 & 40 \\
\hline & $1-3$ & $\mathrm{SC}$ & 2 & 400 & 7 & 60 & 220 & 180 \\
\hline & $5-6$ & LC & 3 & 130 & 3 & 10 & 20 & 110 \\
\hline & $8-9$ & C & 6 & 110 & 2 & 20 & 20 & 90 \\
\hline \multirow[t]{4}{*}{19.} & \multicolumn{3}{|c|}{ Plant matter } & 310 & - & 190 & 260 & 50 \\
\hline & $0-2$ & $\mathrm{C}$ & 3 & 160 & 4 & 20 & 70 & 90 \\
\hline & $3-5$ & $\mathrm{C}$ & 3 & 100 & 3 & 10 & 10 & 90 \\
\hline & $8-10$ & $\mathrm{C}$ & 4 & 100 & 5 & 10 & 10 & 90 \\
\hline \multirow[t]{3}{*}{20.} & $0-1$ & $\mathrm{SC}$ & 3 & 270 & 4 & 50 & 90 & 180 \\
\hline & $1--3$ & $\mathrm{C}$ & 4 & 180 & 4 & 20 & 50 & 130 \\
\hline & $5-7$ & $\mathrm{C}$ & 4 & 160 & 2 & 20 & 30 & 130 \\
\hline \multirow[t]{3}{*}{21.} & $0-2$ & $\mathrm{SC}$ & 4 & 130 & 5 & 50 & 60 & 70 \\
\hline & $3-5$ & $\mathrm{C}$ & 7 & 120 & 2 & 30 & 30 & 90 \\
\hline & $6-8$ & $\mathrm{C}$ & 6 & 250 & 1 & 30 & 30 & 220 \\
\hline \multirow[t]{3}{*}{23} & $0-2$ & $\mathrm{SC}$ & 3 & 290 & 8 & 150 & 180 & 110 \\
\hline & $2-9$ & $\mathrm{SC}$ & 5 & 210 & 7 & 20 & 90 & 120 \\
\hline & $10-13$ & $\mathrm{SC}$ & 7 & 300 & 2 & 30 & 60 & 240 \\
\hline \multirow[t]{3}{*}{24} & $1-3$ & $\mathrm{C}$ & 3 & 210 & 4 & 20 & 20 & 190 \\
\hline & $5-7$ & $\mathrm{C}$ & 3 & 290 & 2 & 20 & 20 & 270 \\
\hline & $11-14$ & LC & 4 & 160 & 2 & 20 & 20 & 140 \\
\hline \multirow[t]{3}{*}{25.} & $0-2$ & EuSC & 3 & 490 & 15 & 100 & 280 & 210 \\
\hline & $3-7$ & EuSC & 5 & 150 & 7 & 10 & 60 & 90 \\
\hline & $8-10$ & EuSC & 7 & 100 & 2 & 0 & 30 & 70 \\
\hline \multirow[t]{3}{*}{27.} & $0-1$ & $\mathrm{BC}$ & 1 & 180 & 11 & 70 & 140 & 40 \\
\hline & $2-3$ & $\mathrm{BC}$ & 2 & 100 & 5 & 50 & 50 & 50 \\
\hline & $5-7$ & $\mathrm{BC}$ & 7 & 120 & 3 & 20 & 40 & 80 \\
\hline \multirow[t]{3}{*}{29.} & $0-2$ & $\mathrm{BC}$ & 1 & 140 & 18 & 50 & 50 & 90 \\
\hline & $3-5$ & $\mathrm{BC}$ & 3 & 130 & 4 & 40 & 30 & 100 \\
\hline & $7-9$ & $\mathrm{BC}$ & 6 & 100 & 4 & 30 & 30 & 70 \\
\hline
\end{tabular}


Table 3. Inorganic and organic phosphorus of some profiles extracted in various pH-ranges.

\begin{tabular}{|c|c|c|c|c|c|c|c|c|c|}
\hline \multirow[b]{2}{*}{ No } & \multirow{2}{*}{$\begin{array}{l}\text { Depth } \\
\text { dm }\end{array}$} & \multirow{2}{*}{$\begin{array}{c}\text { Kind of } \\
\text { peat }\end{array}$} & \multirow[b]{2}{*}{$\mathrm{H}$} & \multirow[b]{2}{*}{$\mathrm{pH}$} & \multicolumn{2}{|c|}{ Inorganic $\mathrm{P}$} & \multicolumn{3}{|c|}{ Organic P } \\
\hline & & & & & ppm & $\begin{array}{l}\% \text { of tot. } \\
\text { inorg. } \mathrm{P}\end{array}$ & ppm & $\begin{array}{c}\% \text { of tot. } \\
\text { org. } \mathrm{P}\end{array}$ & $\begin{array}{l}\% \text { of tot. } \\
\text { extracted }\end{array}$ \\
\hline 1 & 2 & 3 & 4 & 5 & 6 & 7 & 8 & 9 & 10 \\
\hline \multirow[t]{12}{*}{4.} & $0-3$ & LCS & 1 & 2.0 & 86 & 37 & 22 & 2 & 20 \\
\hline & $3-5$ & & 4 & 2.3 & 28 & 16 & 19 & 2 & 40 \\
\hline & $7-10$ & & $\tilde{5}$ & 2.4 & 1 & 1 & 12 & 1 & 90 \\
\hline & $0-3$ & LCS & 1 & 3.6 & 83 & 36 & 30 & 7 & 27 \\
\hline & $3-5$ & & 4 & 3.9 & 4 & 2 & 36 & 4 & 90 \\
\hline & $7-10$ & & 5 & 3.9 & 1 & 1 & 4 & 0.5 & 80 \\
\hline & $0-3$ & LCS & 1 & 7.9 & 95 & 41 & 159 & 35 & 63 \\
\hline & $3-5$ & & 4 & 7.5 & 19 & 11 & 132 & 13 & 87 \\
\hline & $7-10$ & & 5 & 7.8 & 5 & 3 & 52 & 4 & 91 \\
\hline & $0-3$ & LCS & 1 & 9.7 & 116 & 50 & 292 & 65 & 72 \\
\hline & $3-5$ & & 4 & 8.9 & 61 & 34 & 320 & 32 & 84 \\
\hline & $7-10$ & & 5 & 8.9 & 7 & 5 & 237 & 20 & 97 \\
\hline \multirow[t]{12}{*}{15} & & Plant matter & & 2.5 & 113 & 26 & 37 & 8 & 25 \\
\hline & $0-2$ & $\mathrm{SC}$ & 3 & 2.6 & 4 & 4 & 4 & 1 & 50 \\
\hline & $3-5$ & & 2 & 2.8 & 1 & 1 & 0 & 0 & 0 \\
\hline & & Plant matter & & 4.4 & 156 & 36 & 34 & 8 & 18 \\
\hline & $0-2$ & $\mathrm{SC}$ & 3 & 4.4 & 6 & 7 & 6 & 2 & 50 \\
\hline & $3-5$ & & 2 & 4.4 & 0 & 0 & 2 & 1 & 100 \\
\hline & & Plant matter & & 9.2 & 166 & 39 & 173 & 39 & 51 \\
\hline & $0-2$ & $\mathrm{SC}$ & 3 & 8.4 & 18 & 18 & 62 & 16 & 78 \\
\hline & $3-5$ & & 2 & 8.1 & 1 & 2 & 18 & 6 & 95 \\
\hline & & Plant matter & & 11.0 & 187 & 49 & 268 & 60 & 59 \\
\hline & $0-2$ & $\mathrm{SC}$ & 3 & 10.0 & 24 & 24 & 142 & 37 & 86 \\
\hline & $3-5$ & & 2 & 9.6 & 5 & 7 & 69 & 19 & 93 \\
\hline \multirow[t]{12}{*}{18.} & & Plant matter & & 2.7 & 105 & 44 & 20 & 1 & 16 \\
\hline & $1-3$ & $\mathrm{SC}$ & 2 & 2.8 & 3 & 1 & 8 & 1 & 73 \\
\hline & $5-6$ & $\mathrm{LC}$ & 3 & 2.8 & 0 & 0 & 3 & 1 & 100 \\
\hline & & Plant matter & & 4.6 & 158 & 66 & 16 & 1 & 9 \\
\hline & $1-3$ & $\mathrm{SC}$ & 2 & 4.5 & 7 & 2 & 9 & 1 & 56 \\
\hline & $5-6$ & LC & 3 & 4.6 & 0 & 0 & 2 & 0.3 & 100 \\
\hline & & Plant matter & & 8.9 & 152 & 64 & 111 & 33 & 42 \\
\hline & $1-3$ & $\mathrm{SC}$ & 2 & 8.1 & 24 & 7 & 71 & 10 & 75 \\
\hline & $5-6$ & LC & 3 & 8.0 & 4 & 4 & 27 & 5 & 87 \\
\hline & & Plant matter & & 10.8 & 156 & 65 & 168 & 50 & 52 \\
\hline & $1-3$ & $\mathrm{SC}$ & 2 & 9.4 & 49 & 15 & 213 & 29 & 81 \\
\hline & $5-6$ & LC & 3 & 9.5 & 5 & 5 & 123 & 20 & 96 \\
\hline \multirow[t]{6}{*}{22.} & $0-2$ & $\mathrm{SC}$ & 3 & 2.3 & 10 & 4 & 13 & 2 & 56 \\
\hline & $3-9$ & & 5 & 2.1 & 2 & 1 & 13 & 2 & 87 \\
\hline & $10-13$ & & 7 & 2.4 & 0 & 0 & 2 & 0.2 & 100 \\
\hline & $0-2$ & $\mathrm{SC}$ & 3 & 3.5 & 3 & 1 & 13 & 2 & 81 \\
\hline & $3-9$ & & 5 & 3.5 & 2 & 1 & 9 & 1 & 82 \\
\hline & $10-13$ & & 7 & 3.7 & 0 & 0 & 1 & 0.1 & 100 \\
\hline
\end{tabular}




\begin{tabular}{|c|c|c|c|c|c|c|c|c|c|}
\hline 1 & 2 & 3 & 4 & 5 & 6 & 7 & 8 & 9 & 10 \\
\hline & $0-2$ & $\mathrm{SC}$ & 3 & 7.3 & 17 & 7 & 89 & 13 & 84 \\
\hline & $3-9$ & & 5 & 7.1 & 10 & 5 & 45 & 6 & 82 \\
\hline & $10-13$ & & 7 & 7.1 & 2 & 1 & 28 & 3 & 93 \\
\hline & $0-2$ & $\mathrm{SC}$ & 3 & 9.2 & 50 & 19 & 286 & 40 & 85 \\
\hline & $3-9$ & & 5 & 8.8 & 19 & 10 & 146 & 18 & 88 \\
\hline & $10-13$ & & 7 & 9.0 & 2 & 1 & 129 & 15 & 98 \\
\hline \multirow[t]{12}{*}{25.} & $0-2$ & EuSC & 3 & 2.2 & 8 & 2 & 36 & 4 & 82 \\
\hline & $3-7$ & & 5 & 2.5 & 3 & 3 & 4 & 1 & 57 \\
\hline & $8-10$ & & 7 & 2.5 & 1 & 0.5 & 1 & 0.4 & 70 \\
\hline & $0-2$ & EuSC & 3 & 4.1 & 6 & 2 & 37 & 4 & 86 \\
\hline & $3-7$ & & 5 & 4.1 & 2 & 2 & 7 & 1 & 78 \\
\hline & $8-10$ & & 7 & 3.9 & 0 & 0 & 2 & 0.5 & 100 \\
\hline & $0-2$ & EuSC & 3 & 8.7 & 38 & 11 & 136 & 14 & 78 \\
\hline & $3-7$ & & 5 & 7.1 & 8 & 6 & 22 & 4 & 73 \\
\hline & $8-10$ & & 7 & 7.0 & 2 & 2 & 8 & 2 & 80 \\
\hline & $0-2$ & EuSC & 3 & 10.0 & 64 & 18 & 326 & 33 & 84 \\
\hline & $3-7$ & & 5 & 8.8 & 9 & 7 & 71 & 13 & 89 \\
\hline & $8-10$ & & 7 & 8.1 & 2 & 2 & 26 & 8 & 93 \\
\hline \multirow[t]{12}{*}{29.} & $0-2$ & $\mathrm{BC}$ & 1 & 2.6 & 15 & 12 & 9 & 5 & 38 \\
\hline & $3-5$ & & 3 & 2.6 & 3 & 3 & 4 & 1 & 57 \\
\hline & $7-9$ & & 6 & 2.6 & 3 & 4 & 5 & 2 & 63 \\
\hline & $0-2$ & $\mathrm{BC}$ & 1 & 4.3 & 15 & 13 & 11 & 7 & 42 \\
\hline & $3-5$ & & 3 & 4.3 & 1 & 1 & 3 & 1 & 75 \\
\hline & $7-9$ & & 6 & 4.3 & 1 & 2 & 2 & 1 & 63 \\
\hline & $0-2$ & $\mathrm{BC}$ & 1 & 7.7 & 30 & 25 & 21 & 13 & 41 \\
\hline & $3-5$ & & 3 & 7.8 & 6 & 5 & 28 & 6 & 82 \\
\hline & $7-9$ & & 6 & 7.7 & 5 & 6 & 19 & 5 & 79 \\
\hline & $0-2$ & $\mathrm{BC}$ & 1 & 9.1 & 25 & 21 & 65 & 38 & 72 \\
\hline & $3-5$ & & 3 & 9.1 & 11 & 10 & 120 & 27 & 92 \\
\hline & $7-9$ & & 6 & 9.1 & 11 & 14 & 70 & 20 & 86 \\
\hline
\end{tabular}

The $\mathrm{pH}$-values obtained for the samples of the same profile do not differ from each other in such a degree that it would exert a significant effect upon the solubility, except perhaps in the extractions with $0.05 \mathrm{~N}$ sodium hydroxide in some of the series. Even then the differences between the amounts of inorganic phosphorus dissolved from the various layers are so great that no doubt exists of the fact that the absolute and relative amounts of easily soluble inorganic phosphorus are highest in the surface layers and particularly in the undecomposed plant material, and that they show a marked drop with the increase in the depth.

The solubility of organic phosphorus in the various peat layers appears to be similar to that of the inorganic compounds in the respect that the relative amounts extracted decrease with the depth which, however, is not always the case with the absolute quantities. Generally, the proportion of organic phosphorus in the total amount extracted, also enhances with the depth of the layer. 
It would be of interest to get some information on the mechanisms which cause the retention of inorganic and organic phosphorus in peat and which act so intensively in the deeper and more humified layers. These data, however, do not help much to solve this problem. Some assumption could be presented, but it seems to be better to wait for more results on the basis of which the parts played by iron and organic colloids etc. in the retention of phosphorus in peat material would be easier to estimate.

\section{Discussion}

The results reported in the present paper yield, in some respects, a rather clear picture of the forms and solubility of phosphorus in the parts of peat profiles. With an increase in depth the proportion of organic phosphorus in the total phosphorus content of peat increases, whereas the solubility of both inorganic and organic phosphorus decreases often very markedly.

The results concerning the total phosphorus content of the different peat layers do not markedly elucidate the problem of the phosphorus economy in peat land. The loss of dry matter during the decomposition had to be known before any valid comparison of the original phosphorus content of the peat layers could be performed. In addition to this the fact must be remembered that the accumulation of phosphorus in peat deposits is a phenomenon which depends on several factors varying from one case to the other.

In view of all this no valid generalization on the phosphorus economy in peat soils can be drawn. However, the data obtained tempt one to draw some possible outlines. The fact that in the peat lands of better quality the total phosphorus content is often lower in the deeper layers than in the surface may be explained as a result of the rather poor sources of available phosphorus: the growing plants have to fill their need for phosphorus and thus the phosphorus in the cycle concentrates in the surface layers. Yet, a large part of phosphorus in plant residues apparently becomes stored up as organic forms in the peat, and also the inorganic anions seem to be tenaceously fixed. Consequently, the amount of phosphorus in the biological cycle continually decreases, provided no phosphorus is carried from outside. The eutrophic vegetation must build up plant matter poorer in phosphorus, and gradually it has to give way to plant species with lower nutritional requirements. Phosphorus, of course, is not the only factor in this change: also the other nutrients play their role.

In peat lands of lower quality a decrease in the total phosphorus content of the surface layer, as compared with the deeper deposits, was generally observed. In most of the cases also the living plant material was poorer in phosphorus than the peat on which it grew. This indicates that an impoverishment, probably due to the accumulation of phosphorus in forms unavailable to plants takes place.

The more or less complete lack of easily soluble phosphorus in the lower layers may, of course, be explained by the washing out of the soluble forms. In view of 
the facts that the surface layers are generally relatively rich in easily soluble phosphorus, that the phosphorus concentration of the mire water is low, and that there are several mechanisms which can cause the retention of phosphorus in peat it seems probable that the washing out of phosphorus does not play a very marked role in the phosphorus economy of most of the peat lands. This is, however, a problem which requires further study.

Attention must be paid to the fact that the results obtained in the present investigation using air-dry and ground samples probably do not correspond to the solubility conditions in nature. It was found that particularly in the surface samples of S- and CS-peats a large part of the phosphorus was easily soluble. Under natural conditions this phosphorus may be inside the undecomposed plant cells and thus less available to the other plants than what the results of the extractions would indicate.

\section{Sum $m$ ary}

In the present paper results are reported concerning the total content as well as solubility, of organic and inorganic phosphorus in 122 peat samples which were collected from various depths of 30 peat lands.

The total phosphorus content of all the samples was rather low and no regularity in the influence of the depth upon this quantity could be demonstrated. There seemed to be some tendency to an increase in the P-content with increasing depth in the peat lands of lower quality. In peat lands of higher quality the opposite often held true.

A large part of the phosphorus occurred in organic form, and, almost without exception, this percentage of total phosphorus increased with the depth: in undecomposed plant material this proportion was about 50-60 per cent, in the surface layers 70 per cent, on the average, in deposits deeper than $50 \mathrm{~cm}$ seldom less than 80 per cent and it could even reach 95 per cent.

The amount of organic phosphorus expressed as a percentage of organic dry matter was low in most of the samples and although it tended to increase with the depth only in 11 of all the 122 samples values higher than 0.1 per cent were obtained. Even if an allowance is made for the conditions prevailing in peat lands these low percentages of organic phosphorus indicate that, from the microbiological point of view, no rapid mineralization of the organic phosphorus compounds is probable.

The inorganic phosphorus content was low and tended to decrease from the surface to deeper layers. The solubility of inorganic phosphorus, however, dropped much more drastically. Thus in the deeper layers the amount of easily extractable inorganic phosphorus could be negligible. The solubility of organic phosphorus also impaired with the depth.

The phosphorus economy of peat lands was discussed on the basis of the results obtained. 


\section{REFERENCES}

(1) Kaila, A. 1949. Biological absorption of phosphorus. Soil Sci. 68: 279-289

(2) —- 1955. Studies on the colorimetric determination of phosphorus in soil extracts. Acta agr. fenn. 83: $25-47$.

(3) $\longrightarrow$ 1956. Determination of the degree of humification in peat samples. J. Sci. Agr. Soc. Finland $28: 18-35$.

(4) - \& Virtanen, O. 1955. Determination of organic phosphorus in samples of peat soils. Ibid. 27: $104-115$.

(5) Krvinen, E. 1933. Suokasvien ja niiden kasvualustan kasvinravintoainesuhteista. (Referat: Untersuchungen über den Gehalt an Pflanzennährstoffen in Moorpflanzen und an ihren Standorten.) Acta agr. fenn. 27: 1-140.

S E L O T U S :

FOSFORISTA ERÄITTEN LUONNONTILAISTEN SOITTEN ERI KERROKSISSA

ARMI KAILA

Yliopiston maanviljelyskemian laitos, Helsinki

Tutkimuksessa selvitettiin 30:Itä luonnontilaiselta suolta kerätyn 122:n turvenäytteen perusteella eri kerrosten fosforin pitoisuutta ja fosforin liukenevuutta.

Todettiin, että orgaanisen fosforin osuus kokonaisfosforista on tavallisesti sitä suurempi, mitä syvemmältä näyte on otettu: elävässä kasviaineksessa orgaanista fosforia oli noin 50 - $60 \%$ kokonaisfosforista, pintakerroksessa keskimäärin $70 \%$ ja $50 \mathrm{~cm}$ ä syvemmällä harvoin alle $80 \%$.

Sekä orgaanisen että etenkin epäorgaanisen fosforin liukenevuus oli suhteellisesti suurin pintakerroksessa ja aleni syvemmälle mentäessä hyvin nopeasti.

Orgaanisen fosforin prosenttinen osuus orgaanisesta kuiva-aineesta kasvoi yleensä syvempiin kerroksiin siirryttäessä, mutta oli ainoastaan 11 näytteessä suurempi kuin $0.1 \%$. Tämä viittaa siihen, että syvempienkin kerrosten orgaanisen fosforin mineraloituminen tapahtuu hitaasti ja että etenkin pintakerroksissa fosforin biologinen pidättyminen on mahdollista. 